\title{
Photosynthetic plasticity of an invasive variety of Caulerpa racemosa in a coastal Mediterranean area: light harvesting capacity and seasonal acclimation
}

\author{
Raffaella Raniello $^{1, *}$, Maurizio Lorenti ${ }^{1}$, Christophe Brunet $^{2}$, Maria Cristina Buia $^{1}$ \\ ${ }^{1}$ Laboratorio di Ecologia del Benthos, Stazione Zoologica 'A. Dohrn', Punta San Pietro, Ischia Porto, Napoli 80077, Italy \\ ${ }^{2}$ Laboratorio di Oceanografia, Stazione Zoologica 'A. Dohrn', Villa Comunale, Napoli 80121, Italy
}

\begin{abstract}
At the beginning of the 1990s a new strain of Caulerpa racemosa began to spread rapidly throughout most of the Mediterranean Sea. Genetic investigations suggested this new variety could be a recent hybrid between the var. turbinata-uvifera, already present in the Mediterranean basin, and an unknown tropical strain. In summer, the season of maximal biomass development, $C$. racemosa frequently compete with seagrasses. Laboratory experiments based on the construction of $P$ versus $E$ curves and pigment analysis demonstrated the high capacity of this alga to reorganise its photosynthetic apparatus in relation to the available light under the canopy of a Cymodocea nodosa meadow. Using the same methodological approach, we also investigated the adaptive capacity of the var. occidentalis to winter environmental conditions, certainly the most critical for a tropical seaweed. Although maintenance metabolism was also suggested by a remarkable biomass decrease, $C$. racemosa var. occidentalis showed acclimation capacities. The ability of the alga to adapt to different light environments may contribute to its colonisation success in Mediterranean coastal biotopes.
\end{abstract}

KEY WORDS: Caulerpa racemosa var. occidentalis · Photosynthesis · Photoacclimation · Pigments · Cymodocea nodosa

Resale or republication not permitted without written consent of the publisher

\section{INTRODUCTION}

Caulerpa racemosa (Forssk.) J. Agardh is a siphonous green seaweed distributed in tropical and subtropical regions, in which it has an important role both as a primary producer and a structural species (Clifton \& Clifton 1999).

Caulerpa racemosa was first recorded in the Mediterranean Sea in 1926, when it was collected along the Tunisian coast (Hamel 1926, 1931). Later, its presence was reported throughout the eastern basin with 2 varieties, var. turbinata-uvifera and var. lamourouxii, identified on the basis of morphological characteristics. These 2 varieties are also present in the Red Sea, which led to the hypothesis of a lessepsian origin (i.e. entering via the Suez Canal) for the Mediterranean populations (Verlaque et al. 2000). Until very recently, these populations remained stationary (Verlaque et al. 2000).
A new invasive variety, up to now known as occidentalis, has been spreading in the western and eastern Mediterranean Sea since the early 1990s. It seems to be taxonomically and ecologically different from the 2 varieties already present (Verlaque et al. 2000) and does not seem to have a Red Sea origin, since the chronological succession of reports does not follow the typical westward progression of lessepsian species. Moreover, in the Red Sea this variety is limited to Ethiopian coasts, far from the Suez Canal (Taylor 1967). Genetic investigations suggested that the var. occidentalis could be a new hybrid between the variety turbinata-uvifera and an unknown tropical strain (Durand et al. 2002), although the whole issue of correspondence between morphological and molecular data in the definition of Caulerpa racemosa varieties is still under debate (Durand et al. 2002, Famà et al. 2002). 
Caulerpa racemosa sensu lato shows a high morphological plasticity (Ohba \& Enomoto 1987), probably correlated with a physiological one, and, although this species is very relevant in tropical and subtropical regions, the knowledge of its basic biology is very poor. Some investigations were made in its native areas on sexual reproduction and vegetative propagation capacity (Clifton \& Clifton 1999) and on the production

of allelopathic substances and their role as defence against predators (Paul \& Meyer. 1986, Meyer \& Paul 1992). However, only a few studies have been performed on its photosynthetic characteristics. Gattuso \& Jaubert (1985) found an increase in both respiration and photosynthetic rates for the variety clavifera, in relation to short-term temperature increase in an aquarium. By studying photoacclimation in an aquarium, Riechert \& Dawes (1986) obtained interesting data about photosynthetic plasticity in var. uvifera. In particular, they noticed variations in chloroplast volume, chlorophyll $b$ vs chlorophyll $a$ ratio, and siphonaxanthin vs chlorophyll $a$ ratio in relation to the irradiance level. Moreover they found that, while $P_{\mathrm{m}}$ changed in the light acclimation process, $E_{k}$ remained constant and photoinhibition suddenly occurred at a fixed irradiance without any plateau in the $P$ versus $E$ curve, suggesting a genetic limitation to high light levels.

In the Mediterranean Sea, studies on Caulerpa racemosa var. occidentalis have mainly been based on in situ manipulation experiments aimed at elucidating its interactions with seaweeds and seagrasses. Mechanisms of competition are only hypothesized, and its ecophysiology has not been studied. Some investigations revealed a substantial negative effect of this species on resident benthic flora (Piazzi et al. 2001), pointing to structural modifications of the benthic macroalgal community induced by the C. racemosa invasion. Ceccherelli et al. (2000) and Ceccherelli \& Campo (2002) studied the effects of C. racemosa var. occidentalis introduction on a seagrass community in the Mediterranean Sea. Their work revealed stressful conditions for Cymodocea nodosa (Ucria) Ascherson, Nanozostera noltii Hornemann (Tomlinson \& Posluzny) and Posidonia oceanica (L) Delile. Any negative effects on seagrass meadows are of great concern, in view of their major importance among the Mediterranean coastal ecosystems (Buia et al. 2000).

Studies on the photosynthetic plasticity of Caulerpa racemosa var. occidentalis are therefore warranted, in order to clarify the potential relationships between these characteristics and the high invasive capacity.

Thus, in the present work 2 fundamental aspects were investigated: (1) In summer, the season of maximal biomass development, Caulerpa racemosa var. occidentalis frequently co-occurs with Cymodocea nodosa on sandy substrata in shallow water. In fact, this alga seems to have a higher colonization success on sandy substrata pre-colonized and consequently stabilized by seagrasses. Under these conditions, the photosynthetic apparatus capacity in the exploitation of light filtered by the seagrass canopy could be fundamental. Thus, experiments based on the construction of $P$ versus $E$ curves and pigment analysis were performed, in order to investigate the capacity of the algae to reorganize its photosynthetic apparatus in relation to the optimal exploitation of available light under the C. nodosa canopy. (2) For a tropical alga the most critical season in the Mediterranean Sea is expected to be winter. For this reason, the adaptive capacity of the var. occidentalis to winter environmental conditions was also investigated, using the same experimental approach reported above. The aim was to understand whether C. racemosa var. occidentalis acclimates (or shows tolerance) to winter conditions, different from those typical of its area of origin.

\section{MATERIALS AND METHODS}

Study site and plant material. Caulerpa racemosa thalli were collected at shallow depths (3 to $5 \mathrm{~m}$ ) from a sampling site located at Castello Aragonese, Island of Ischia, Gulf of Naples $\left(40^{\circ} 43^{\prime} \mathrm{N}, 13^{\circ} 57^{\prime} \mathrm{E}\right)$. In summer (August 2001), thalli were collected from a $5 \mathrm{~m}$ deep Cymodocea nodosa meadow, characterised by 2 levels of shoot cover, dense (Dm) and sparse ( $\mathrm{Sm})$, as well as from nearby rocks at $3 \mathrm{~m}$ depth (RS = rocks in summer). In winter (February 2002), due to the lack of $C$. racemosa in the meadow, only thalli growing on rocks were sampled (RW = rocks in winter).

Prior to experiments, thalli were kept in the laboratory in running seawater at the temperature recorded in the field $\left(25\right.$ or $27^{\circ} \mathrm{C}$ in summer and $14.5^{\circ} \mathrm{C}$ in winter). Preliminary analysis revealed that such conditions did not significantly alter the alga's photosynthetic performance for up to $1 \mathrm{wk}$ (R.R. unpubl. data).

Upon collection, thalli used for the determination of pigments were cleaned free from epiphytes and immediately stored at $-20^{\circ} \mathrm{C}$ to minimize any change in pigment content.

Field light measurements. Maximum noon scalar irradiance $\left(E_{\mathrm{m}}\right)$, expressed as $\mu \mathrm{mol} \mathrm{m}{ }^{-2} \mathrm{~s}^{-1}$, was determined on 2 typical sunny days, in summer and in winter respectively, by means of a QSI-140 quantum meter (Biospherical Instruments). Measurements were taken immediately above and within the Cymodocea nodosa canopy in both dense and sparse meadows in summer and above the nearby rocks in both summer and winter. Light transmission in the canopy was calculated as a percentage of the above canopy irradiance. 
Estimation of daily $\boldsymbol{H}_{\text {sat }}$. The daily period of photosynthetically saturating irradiance $\left(H_{\text {sat }}\right)$ was estimated for each growth condition of Caulerpa racemosa using the formula from Zimmermann et al. (1995):

$$
H_{\text {sat }}=D\left[1-(2 / \pi) \times \sin ^{-1}\left(E_{k} / E_{\mathrm{m}}\right)\right]
$$

where $D$ is the daily photoperiod in h, $E_{k}$ is the irradiance required to saturate photosynthesis and $E_{\mathrm{m}}$ is the maximum noon scalar irradiance.

Pigment analysis. Chlorophyll content of thallus sections used for the photosynthesis experiments was determined spectrophotometrically in $90 \%$ acetone extracts, according to Jeffrey \& Humphrey (1975).

Photosynthetic pigment identification and quantification were made by HPLC (high pressure liquid chromatography). Pigments from $0.3 \mathrm{~g}$ of frozen tissue were extracted with a mini-Potter homogenizer in $100 \%$ acetone saturated with $\mathrm{CaCO}_{3}$. The extract was diluted to $50 \%$ in methanol and $300 \mu \mathrm{l}$ of ammonium acetate $(1 \mathrm{M})$ was added to $1 \mathrm{ml}$ of extract. After $5 \mathrm{~min}$, the extract was injected in a Hewlett Packard Series 1100 HPLC. A $3 \mu \mathrm{m} \mathrm{C}_{8}$ BDS column $(100 \times 4.6 \mathrm{~mm})$ was used and the mobile phase was composed of 2 solvent mixtures: A (methanol:aqueous ammonium acetate, 70:30) and B (methanol). The gradient between the solvents was the same as in Vidussi et al. (1996). Pigments were detected at $440 \mathrm{~nm}$ using a HP photodiode array detector Model DAD Series 1100, which gives the 400-700 nm spectrum for each detected pigment. Single pigments were identified and quantified using chlorophyll and carotenoid standards obtained from the VKI (Water Quality Institute, International Agency for ${ }^{14} \mathrm{C}$ Determination, Denmark). Whenever pigment standards were not available, quantification was accomplished by applying specific extinction coefficients from the literature.

Estimates of photosynthesis versus irradiance parameters. Photosynthesis and respiration of Caulerpa racemosa were estimated from oxygen evolution rates of thallus fragments in 2 Clark-type electrodes (Rank Bros) connected to a 2-channel chart recorder. The apparatus is fundamentally as described in James \& Larkum (1996). Each electrode was fitted to a $5 \mathrm{ml}$ incubation chamber filled with filtered seawater. Temperature around the electrode chamber was controlled by means of a Braun circulating water bath. Light was provided by a Leitz Pradovit slide projector and neutral density filters were used to change irradiance levels.

Thallus portions of about $3 \mathrm{~cm}$ were placed within the electrode chamber at a salinity of 38 psu and at a temperature of $14.5,25$ or $27^{\circ} \mathrm{C}$, depending upon the value recorded in the field at the time of collection. Thallus portions were exposed to 18 irradiance levels ranging from 0 to $1400 \mu \mathrm{mol} \mathrm{m}^{-2} \mathrm{~s}^{-1}$, measured with the quantum scalar irradiance meter. Following the expo- sure to each irradiance level (lasting at least $2 \mathrm{~min}$ ), dark respiration (R) was measured.

Rates of oxygen evolution at different irradiances, normalized both to biomass (fresh weight, fw) and chlorophyll a content of the thallus fragments, were used to generate $P$ versus $E$ curves. The main $P$ versus $E$ characteristics (maximum photosynthetic rate, $P_{\mathrm{m}}$ i irradiance required to saturate photosynthesis, $E_{k}$ ) were modelled and described with the exponential function of Webb et al. (1974), using SigmaPlot software (SPSS) for elaboration. Quadratic or hyperbolic functions used with our data did not show higher model skills in terms of $\mathrm{R}^{2}$ (data not shown). The initial slope of photosynthesis $(\alpha)$ was calculated as the ratio between $P_{\mathrm{m}}$ and $E_{k}$, while the compensation irradiance $\left(E_{\mathrm{c}}\right)$ was estimated from the ratio $R$ versus $\alpha$. $R$ was determined as the mean of dark respiration rates measured after exposure to different irradiances.

Short-term acclimation experiments. Experiments aiming to study the short-term acclimation were performed by keeping summer thalli, collected on rocky substratum, overnight at $14.5^{\circ} \mathrm{C}$ (in situ winter temperature), prior to the determination of $P$ versus $E$ curves. These thalli will be referred to in the following as RSa (RS acclimated thalli).

Experimental design and statistical treatment. Nine $P$ versus $E$ curves were generated for each growth condition (Sm, Dm, RW, RS and RSa) by using an individual thallus portion for each curve. In order to exclude any site effect, 3 thalli were collected from each of 3 different sparse $(\mathrm{Sm})$ areas and 3 different dense (Dm) areas within the Cymodocea nodosa meadow and, similarly, both in winter and in summer, samples from the rocky substrate were taken at 3 different areas (for a total number of 9 replicates).

Two additional thalli from each area were collected and used for pigment composition analysis, yielding a total of 6 replicates for each growth condition.

A Student's $t$-test was performed to compare the data sets relative to $\mathrm{Sm}$ and $\mathrm{Dm}$ conditions, in the Cymodocea nodosa meadow, and to compare RS and RW samples or RSa and RW samples.

\section{RESULTS}

On a typical sunny day in summer, an $E_{\mathrm{m}}$ value of $834 \mu \mathrm{mol} \mathrm{m}^{-2} \mathrm{~s}^{-1}$ was measured above the canopy of Cymodocea nodosa, while, on the same day, $E_{\mathrm{m}}$ values recorded within the dense and the sparse canopy were 332 and $709 \mu \mathrm{mol} \mathrm{m}^{-2} \mathrm{~s}^{-1}$, respectively. Light transmission values were therefore estimated to be $40 \%$ in the dense canopy and $85 \%$ in the sparse one. On the rocky substrate values of 1000 and of $600 \mu \mathrm{mol} \mathrm{m}{ }^{-2} \mathrm{~s}^{-1}$ were recorded in summer and winter sunny days, respec- 


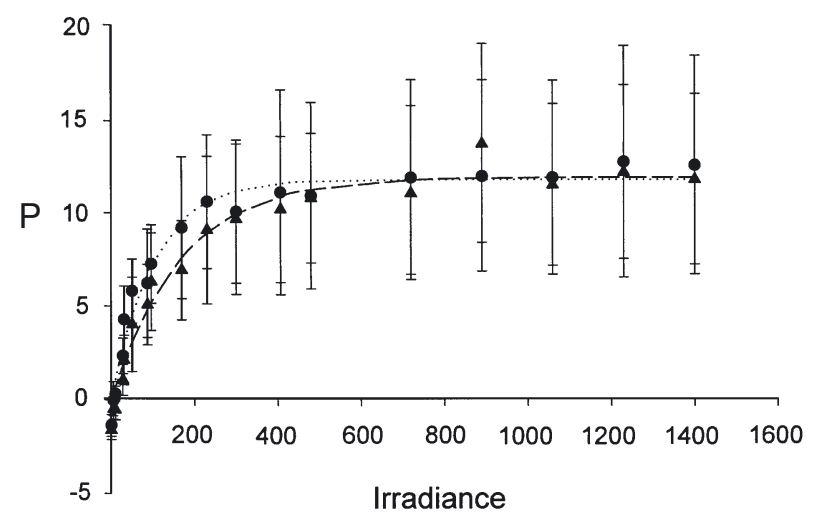

Fig. 1. Mean $P$ versus $E$ curves for Dm (dotted line and circles) and $\mathrm{Sm}$ (dashed line and triangles) samples. Irradiance in $\mu \mathrm{mol} \mathrm{m} \mathrm{m}^{-2} \mathrm{~s}^{-1}$; photosynthetic rate in $\mu \mathrm{mol} \mathrm{O}_{2} \mathrm{~g}^{-1} \mathrm{fw} \mathrm{h}^{-1}$

tively. On the days in which measurements were taken, water clarity conditions were similar, with an attenuation coefficient of PAR equal to $0.3 \mathrm{~m}^{-1}$.

$H_{\text {sat }}$ periods were 11.9 and $12.5 \mathrm{~h}$, respectively, for dense and sparse growth conditions in summer. On the rocky substratum, the $H_{\text {sat }}$ periods were $8 \mathrm{~h}$ in winter and 13.5 in summer.

\section{Dense and sparse Cymodocea nodosa meadow areas comparison}

Mean values of photosynthetic parameters from $P$ versus $E$ curves (Fig. 1), and of dark respiration and $E_{\mathrm{c}}$ are provided in Table 1 . The $P_{\mathrm{m}}$ value normalized to the chlorophyll a content $\left(P_{\mathrm{m}}-\mathrm{chl}\right)$ was significantly higher $(\mathrm{p} \leq 0.05)$ in the Sm samples $(0.15 \mu \mathrm{mol}$ $\mathrm{O}_{2} \mu \mathrm{g} \mathrm{chl} a^{-1} \mathrm{~h}^{-1}$ ) than in Dm samples (0.09 $\left.\mu \mathrm{mol} \mathrm{O}_{2} \mu \mathrm{g} \mathrm{chl} a^{-1} \mathrm{~h}^{-1}\right)$, while $P_{\mathrm{m}}$ values for $\mathrm{Sm}$ and Dm samples were not significantly different if normalized to gram of fresh weight $\left(P_{\mathrm{m}}-\mathrm{fw}\right)$. The $\alpha$ parameter also showed a significant difference ( $p \leq 0.01)$, being twice as high for samples collected in the dense Cymodocea nodosa meadow than in the sparse one, while $E_{k}$ was significantly higher in the sparse condition of growth than in the dense one. The respiration rate did not seem to be influenced by the different growth conditions. The different values of $\alpha$ associated to the same dark respiration value yielded a different $E_{\mathrm{c}}$ value between dense and sparse condi- tions $\left(15 \mu \mathrm{mol}\right.$ photons $\mathrm{m}^{-2} \mathrm{~s}^{-1}$ and $29 \mu \mathrm{mol}$ photons $\mathrm{m}^{-2} \mathrm{~s}^{-1}$, respectively).

Results on pigment composition in the 2 light conditions (Sm and $\mathrm{Dm}$ ) are summarized in Table 2. Chlorophyll $a$, chlorophyll $b$, siphonaxanthin and siphonein concentrations (in $\mu g$ per gram of fw) were significantly higher $(\mathrm{p} \leq 0.01)$ in samples from high density $(\mathrm{Dm})$ than from low density meadow $(\mathrm{Sm})$. Lutein and antheraxanthin concentrations were significantly higher $(p \leq 0.01)$ in $\mathrm{Sm}$ than in Dm thalli, while zeaxanthin was not found in our samples, even at the highest irradiance levels. In thalli collected in dense meadow, the values of chlorophyll $b$ versus chlorophyll $a$, siphonaxanthin versus chlorophyll $a$ and siphonein versus chlorophyll $a$ were higher $(\mathrm{p} \leq 0.01)$ than values obtained for thalli from the sparse meadow. The (siphonaxanthin + siphonein) versus lutein ratio was dramatically higher under the lowest light regime than under the highest one.

\section{Winter and summer comparisons}

Results of the comparisons between photosynthetic performances of summer and winter thalli, analysed at field temperature, are reported in Table 3a. Mean $P$

Table 1. Mean values $\pm \mathrm{SE}$ of $P$ versus $E$ curve parameters for $\mathrm{Sm}$ and $\mathrm{Dm}$ samples $\left(P_{\mathrm{m}}\right.$-chl $=P_{\mathrm{m}}$ by chl a $\mu g_{;} P_{\mathrm{m}}$-fw $=P_{\mathrm{m}}$ by $\mathrm{g} \mathrm{fw} ; E_{\mathrm{k}}=$ saturating irradiance $E_{\mathrm{c}}=\mathrm{com}-$ pensation irradiance; $\alpha=$ photosynthetic efficiency; $R=$ dark respiration). $\mathrm{p}=$ significance level of Student's $t$-test

\begin{tabular}{|c|c|c|c|}
\hline & Sm samples & Dm samples & $\mathrm{p}$ \\
\hline$P_{\mathrm{m}}-\operatorname{chl}\left(\mu \mathrm{mol} \mathrm{O}{ }_{2} \mu \mathrm{g}(\operatorname{chl~a})^{-1} \mathrm{~h}^{-1}\right)$ & $0.15 \pm 0.07$ & $0.09 \pm 0.03$ & $\leq 0.05$ \\
\hline$P_{\mathrm{m}}-\mathrm{fw}\left(\mu \mathrm{mol} \mathrm{O} \mathrm{O}_{2} \mathrm{~g}-\mathrm{fw}^{-1} \mathrm{~h}^{-1}\right)$ & $12.19 \pm 4.48$ & $11.76 \pm 5.85$ & 0.83 \\
\hline$\alpha$ & $0.06 \pm 0.02$ & $0.10 \pm 0.04$ & $\leq 0.01$ \\
\hline$E_{k}\left(\mu \mathrm{mol} \mathrm{m} \mathrm{m}^{-2} \mathrm{~s}^{-1}\right)$ & $198 \pm 38$ & $107 \pm 34$ & $\leq 0.01$ \\
\hline$R\left(\mu \mathrm{mol} \mathrm{O}{ }_{2} \mathrm{~g}-\mathrm{fw}^{-1} \mathrm{~h}^{-1}\right)$ & $1.91 \pm 0.59$ & $1.59 \pm 0.58$ & 0.18 \\
\hline$E_{\mathrm{c}}\left(\mu \mathrm{mol} \mathrm{m} \mathrm{m}^{-2} \mathrm{~s}^{-1}\right)$ & $29 \pm 7$ & $15 \pm 4$ & $\leq 0.01$ \\
\hline
\end{tabular}

Table 2. Mean values $\pm \mathrm{SE}$ of $\mathrm{Sm}$ and Dm sample pigment content $\left(\mu \mathrm{g} \mathrm{g}^{-1} \mathrm{fw}\right)$ and ratios between selected pigments. chl $a=$ chlorophyll $a_{\text {; }}$ siphn $=$ siphonein; $\operatorname{siph} \mathrm{x}=$ siphonaxanthin; lut $=$ lutein. $\mathrm{p}=$ significance level of Student's $t$-test

\begin{tabular}{|lrrr|}
\hline & Dm samples & Sm samples & $\mathrm{p}$ \\
\hline Chlorophyll $a$ & $23.02 \pm 1.48$ & $12.83 \pm 2.40$ & $\leq 0.01$ \\
Chlorophyll $b$ & $9.79 \pm 0.55$ & $4.49 \pm 0.87$ & $\leq 0.01$ \\
Siphonaxanthin & $11.83 \pm 0.70$ & $4.26 \pm 1.31$ & $\leq 0.01$ \\
Siphonein & $14.59 \pm 1.30$ & $6.64 \pm 1.62$ & $\leq 0.01$ \\
Lutein & $0.30 \pm 0.005$ & $0.94 \pm 0.27$ & $\leq 0.01$ \\
Antheraxanthin & $0.47 \pm 0.01$ & $0.84 \pm 0.15$ & $\leq 0.01$ \\
Violaxanthin & $6.88 \pm 2.67$ & $5.72 \pm 1.74$ & 0.39 \\
Chlorophyll b/chl a & $0.43 \pm 0.02$ & $0.35 \pm 0.02$ & $\leq 0.01$ \\
Siphonaxanthin/chl a & $0.51 \pm 0.03$ & $0.33 \pm 0.08$ & $\leq 0.01$ \\
Siphonein/chl $a$ & $0.63 \pm 0.06$ & $0.52 \pm 0.08$ & $\leq 0.01$ \\
(siphn+siphx)/lut & $91.65 \pm 16.38$ & $11.94 \pm 2.24$ & $\leq 0.01$ \\
\hline
\end{tabular}


Table 3. Mean values \pm SE of $P$ versus $E$ curve parameters. (a) At in situ temperature for RS and RW thalli; (b) at $14.5^{\circ} \mathrm{C}$ for RW and RSa thalli. For definitions of parameter see Table 1. $\mathrm{p}=$ significance level of Student's $t$-test

\begin{tabular}{|c|c|c|c|}
\hline & RS thalli & RW thalli & $\mathrm{p}$ \\
\hline \multicolumn{4}{|l|}{ (a) } \\
\hline$P_{\mathrm{m}}-\mathrm{fw}\left(\mu \mathrm{mol} \mathrm{O} \mathrm{g}^{-1} \mathrm{fw} \mathrm{h}^{-1}\right)$ & $18.69 \pm 5.09$ & $6.66 \pm 1.65$ & $\leq 0.01$ \\
\hline$E_{k}\left(\mu \mathrm{mol} \mathrm{m}{ }^{-2} \mathrm{~s}^{-1}\right)$ & $156 \pm 44$ & $74 \pm 16$ & $\leq 0.01$ \\
\hline$\alpha$ & $0.12 \pm 0.02$ & $0.11 \pm 0.03$ & 0.35 \\
\hline$R\left(\mu \mathrm{mol} \mathrm{O}{ }_{2} \mathrm{~g}^{-1} \mathrm{fw} \mathrm{h}^{-1}\right)$ & $2.01 \pm 0.71$ & $1.42 \pm 0.90$ & 0.14 \\
\hline$E_{\mathrm{c}}\left(\mu \mathrm{mol} \mathrm{m} \mathrm{m}^{-2} \mathrm{~s}^{-1}\right)$ & $18 \pm 8$ & $14 \pm 9$ & 0.38 \\
\hline \multicolumn{4}{|l|}{ (b) } \\
\hline$P_{\mathrm{m}}-\operatorname{chl}\left(\mu \mathrm{mol} \mathrm{O} \mathrm{O}_{2} \mu \mathrm{g}(\mathrm{chl} \mathrm{a})^{-1} \mathrm{~h}^{-1}\right)$ & $0.05 \pm 0.01$ & $0.05 \pm 0.02$ & 0.29 \\
\hline$P_{\mathrm{m}}-\mathrm{fw}\left(\mu \mathrm{mol} \mathrm{O} \mathrm{g}^{-1} \mathrm{fw} \mathrm{h}^{-1}\right)$ & $5.70 \pm 1.44$ & $6.66 \pm 1.65$ & 0.21 \\
\hline$E_{\mathrm{k}}\left(\mu \mathrm{mol} \mathrm{m} \mathrm{m}^{-2} \mathrm{~s}^{-1}\right)$ & $29 \pm 7$ & $74 \pm 16$ & $\leq 0.01$ \\
\hline$E_{\mathrm{c}}\left(\mu \mathrm{mol} \mathrm{m} \mathrm{s}^{-2} \mathrm{~s}^{-1}\right)$ & $3 \pm 1$ & $14 \pm 9$ & $\leq 0.01$ \\
\hline$\alpha$ & $0.20 \pm 0.04$ & $0.11 \pm 0.03$ & $\leq 0.01$ \\
\hline$R\left(\mu \mathrm{mol} \mathrm{O}{ }_{2} \mathrm{~g}^{-1} \mathrm{fw}^{-1}\right)$ & $0.64 \pm 0.10$ & $1.42 \pm 0.90$ & $\leq 0.05$ \\
\hline
\end{tabular}

Table 4. Mean values \pm SE of pigment concentration $\left(\mu \mathrm{g} \mathrm{g}^{-1} \mathrm{fw}\right)$ and pigment ratios of RS and RW samples. vio = violaxanthin; ant = antheraxanthin; zea $=$ zeaxanthin (for definitions of other parameters see Table 2). p = significance level of Student's $t$-test

\begin{tabular}{|lccc|}
\hline & RS thalli & RW thalli & $\mathrm{p}$ \\
\hline Chlorophyll $a$ & $11.25 \pm 2.34$ & $23.36 \pm 5.66$ & $\leq 0.01$ \\
Chlorophyll $b / \mathrm{chl} a$ & $0.34 \pm 0.02$ & $0.31 \pm 0.03$ & 0.07 \\
Siphonaxanthin/chl $a$ & $0.25 \pm 0.04$ & $0.24 \pm 0.06$ & 0.65 \\
Siphonein/chl $a$ & $0.41 \pm 0.02$ & $0.47 \pm 0.11$ & 0.27 \\
Lutein/chl $a$ & $0.010 \pm 0.005$ & $0.034 \pm 0.011$ & $\leq 0.01$ \\
(siphn+siphx)/lut & $78.80 \pm 42.32$ & $21.17 \pm 5.98$ & $\leq 0.05$ \\
Zeaxanthin/chl a & 0 & $0.02 \pm 0.01$ & $\leq 0.01$ \\
Antheraxanthin/chl a & $0.03 \pm 0.01$ & $0.14 \pm 0.04$ & $\leq 0.01$ \\
Violaxanthin/chl a & $0.38 \pm 0.04$ & $0.38 \pm 0.03$ & 0.78 \\
(vio+ant+zea)/chl $a$ & $0.41 \pm 0.04$ & $0.55 \pm 0.07$ & $\leq 0.01$ \\
zea/(vio+ant+zea) & 0 & $0.04 \pm 0.01$ & $\leq 0.01$ \\
ant/(vio+ant+zea) & $0.08 \pm 0.02$ & $0.26 \pm 0.06$ & $\leq 0.01$ \\
& & & \\
\hline
\end{tabular}

0.01). The (vio+ant+zea) versus chl $a$, antheraxanthin versus (vio+ant+zea) and zeaxanthin versus (vio+ant+zea) ratios, corresponding to the so-called photoprotective xanthophyll cycle, were significantly higher ( $\mathrm{p} \leq 0.01)$ in RW thalli.

Results of short-term acclimation to winter temperature of summer thalli (RSa) are reported in Table 3b. After an overnight acclimation of summer thalli to the temperature recorded in February in the field $\left(14.5^{\circ} \mathrm{C}\right), P$ versus $E$ curves were performed at the same temperature. Comparing RSa and RW sample performances, recorded at $14.5^{\circ} \mathrm{C}$, significant differences in $E_{k}$ (higher in RW), $\alpha$ (higher in RSa), $R$ (higher in RW) and consequently in $\mathrm{E}_{\mathrm{c}}$ were found. $P_{\mathrm{m}}$-chl and $P_{\mathrm{m}}$-fw were not different between summer and winter thalli.

\section{DISCUSSION}

\section{Dense and sparse Cymodocea nodosa meadow comparisons}

Although benefitting from significant advantages in terms of substrate stability and edaphic resources, Caulerpa racemosa living in Cymodocea nodosa meadows grows in a highly spatially variable light environment. In fact, in the Mediterranean coastal site studied, thalli growing in the dense portion of the meadow experience a reduction of ca. $50 \%$ of light availability in comparison to thalli growing among sparse shoots. versus $E$ curves for RW and RS thalli are represented in Fig. 2. $P_{\mathrm{m}}$ normalized to gram of fw was significantly different $(\mathrm{p} \leq 0.01)$ between winter and summer samples $\left(6.66 \mu \mathrm{mol} \mathrm{O} \mathrm{g}^{-1}\right.$ fw and $18.69 \mu \mathrm{mol} \mathrm{O} \mathrm{g}^{-1} \mathrm{fw}$, respectively) as well as $E_{k}$, which was twice as high for summer thalli than for winter ones $(\mathrm{p} \leq 0.01)$. However, $\alpha, R$ and consequently $E_{\mathrm{C}}$ did not differ between RW and RS thalli, suggesting a lack of regulation by the seasonal cycle for these parameters.

Results for pigment composition are summarized in Table 4. Chlorophyll a concentration was significantly higher $(\mathrm{p} \leq 0.01)$ in winter than in summer thalli, while chlorophyll $b$, siphonaxanthin and siphonein versus chlorophyll a ratios were not significantly different in the 2 seasons. However, the lutein versus chlorophyll $a$ ratio was significantly higher $(\mathrm{p} \leq 0.01)$ in RW samples than in RS ones. Similar results were found for antheraxanthin and zeaxanthin versus chlorophyll a ratios $(\mathrm{p} \leq$

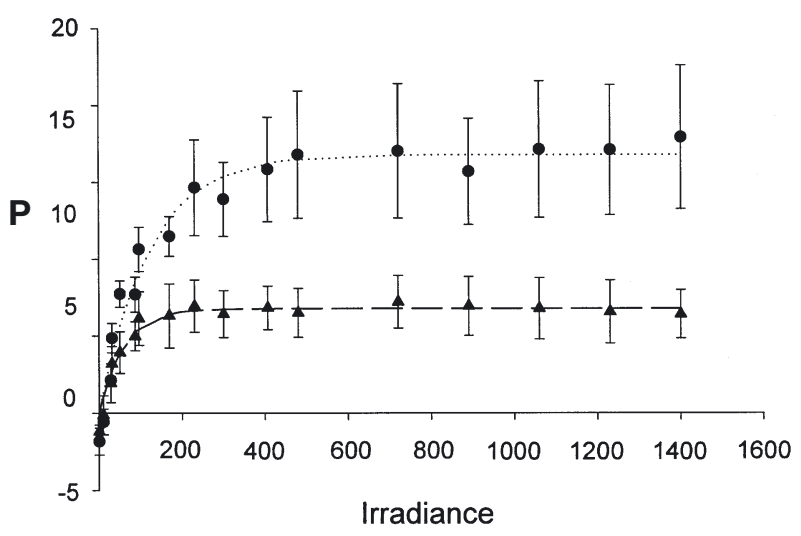

Fig. 2. Mean $P$ verus $E$ curves for RS (dotted line and circles) and RW (dashed line and triangles) thalli at in situ temperature $\left(27^{\circ} \mathrm{C}\right.$ in summer and $14.5^{\circ} \mathrm{C}$ in winter). Irradiance in $\mu \mathrm{mol} \mathrm{m} \mathrm{m}^{-2} \mathrm{~s}^{-1}$; photosynthetic rate in $\mu \mathrm{mol} \mathrm{O}_{2} \mathrm{~g}^{-1} \mathrm{fw} \mathrm{h}^{-1}$ 
Under the 2 conditions considered here, Caulerpa racemosa var. occidentalis does not seem to experience different levels of physiological stress in relation to light availability and/or competition with Cymodocea nodo$s a$, as far we can judge from the lack of difference in respiration rates between $\mathrm{Dm}$ and $\mathrm{Sm}$ thalli. On the contrary, there is an adaptation of the photosynthetic characteristics to both conditions, as shown by their significant differences in Dm and Sm thalli.

Results can be interpreted as modifications in size and arrangement of the photosynthetic apparatus. Assuming a defined turnover time for the reaction centres (RCs), $P_{\mathrm{m}}$-fw can be used as an index of the number of reaction centres per unit biomass (Lobban et al. 1985). In this case, high values of $P_{\mathrm{m}}$-fw correspond to a high number of RCs. $P_{\mathrm{m}}$-chl concentration is related to the percentage of chlorophyll a located in the light harvesting system. Considering a definite turnover time for RCs, a low value of $P_{\mathrm{m}}$-chl corresponds to a high percentage of total chlorophyll $a$ in the harvesting system (Lobban et al. 1985). Thus, the non-significant difference of $P_{\mathrm{m}}$-fw, together with significant difference for $P_{\mathrm{m}}$-chl, suggests that in the 2 light conditions the alga has the same number of reaction centres by unit of biomass, but a different percentage of total chlorophyll a located in the light harvesting system. This could be due to a different requested efficiency in the light harvesting in relation to a different light regime, as also revealed by the twice as high value of $\alpha$ (an index of the light-harvesting system efficiency) in the dense rather than in the sparse Cymodocea nodosa meadow. This result reveals a strong adaptation of the Caulerpa racemosa var. occidentalis photosynthetic apparatus to the light characteristics of its microhabitat. The same applies to saturation irradiance $\left(E_{k}\right)$, which showed a lower value at the lowest light condition. This difference in $E_{k}$ determines the increase in the length of the $H_{\text {sat }}$ period available to Dm thalli, allowing the alga to be light saturated for a longer period per day also under the dense canopy.

Differences in $E_{k}$ between Dm and Sm thalli and the absence of photo-inhibition disagree with the previously commented results of Riechert \& Dawes (1986) on Caulerpa racemosa var. uvifera. Photoacclimation is also clear considering pigment composition. Chlorophyll a concentration in C. racemosa tissue is higher in Dm than in Sm thalli, which concurs with the previous hypothesis on the presence of more chlorophyll a molecules in the light harvesting system. Under the dense canopy of Cymodocea nodosa, chlorophyll $b$, siphonaxanthin and siphonein show the same trend (increasing values), linked to an increase of light harvesting system efficiency, especially in the exploitation of green light (Kageyama at al. 1977, Yokohama et al. 1977, Yokohama 1981). In fact, green light could be rel- evant in this ecosystem, since other wavelengths can be already harvested by the seagrass leaves, before reaching the alga upright axes. In contrast, lutein was more abundant in the sparse meadow than in the dense one. This result is coherent with the fact that lutein is considered a photoprotective pigment (Yokohama 1983). In Dm thalli, the (siphonaxantin + siphonein) versus lutein ratio is higher than in Sm thalli, in agreement with these pigments' roles and with their biosynthetic relationship. In fact, the relationship among these 3 pigments has been established and lutein is considered the precursor of siphonaxanthin, from which siphonein is synthesized by oxidation (Yokohama 1983).

A well-known pigment cycle is the so-called 'xanthophyll cycle', based on violaxanthin-antheraxanthinzeaxanthin interconversion. In this light-dependent reversible cycle, zeaxanthin and antheraxanthin work as photoprotective pigments (Demmig et al. 1988, Demmig-Adams 1990, Vershinin \& Kamnev 1996, Young \& Frank 1996). Antheraxanthin concentration is higher in Sm thalli (much more exposed to high light) than in Dm ones, while zeaxanthin is not revealed either in Sm or in Dm thalli. Assuming that no loss of zeaxanthin has occurred in the short time between collection of samples and their freezing, this result suggests that light intensity is not sufficient to induce the complete activation of the xanthophyll cycle, even in the low density areas. Moreover no line downturn, associated with photoinhibition, occurred in the $P$ versus $E$ curves, contrary to results by Riechert \& Dawes (1986). These results could be explained by the tropical origin of the analysed species, which is probably well adapted to the high light regime typical of tropical regions.

\section{Winter and summer comparisons}

A major issue when dealing with algae of tropical origin is adaptation to the seasonal variability typical of temperate seas. Caulerpa racemosa achieves a biomass maximum in summer and a minimum in winter, with thalli made up only by short stolones with sparse upright axes (pers. obs.).

By comparing $P$ versus $E$ curves derived for RS and RW samples, respectively, summer and winter in field temperatures, a survival metabolism was in winter, and this was suggested by the consistent biomass reduction observed in this season. Both $P_{\mathrm{m}}$-fw and $E_{k}$ were significantly lower in winter. The decline in $E_{k}$ allows a lengthening of $H_{\text {sat, }}$ while, on the other hand, quantum efficiency $(\alpha)$ does not seem to increase in comparison to summer, so that an increase in the exploitation of subsaturing irradiance is not achieved. Yet, dark respiration also turns out to be independent of the seasonal cycle. The observation that $R$ was equivalent in summer and in 
winter, in spite of the kinetic effect of temperature, may justify the formulation of 2 alternative theories. The first one consists of an increased number of catabolic reactions connected with increasing energetic needs, due to 'low temperature' stress; the second one concerns an acclimation process, in which the synthesis of a larger amount of enzymes or the synthesis of alloenzymes would compensate for the kinetic effect of temperature. No supposition about molecular organization of the photosynthetic apparatus in summer and winter could be formulated on the basis of data collected at different temperatures for summer and winter thalli, respectively. Under these conditions, in fact, the physiological consequences of a possible different organisation of the photosynthetic apparatus in summer and in winter could be confused with the temperature kinetic effect on $P$ versus $E$ performance. Thus, as for summer thalli, dark respiration rate was determined at in situ winter temperature, after an overnight acclimation. Under this condition, summer thalli (RSa) showed a lower respiration rate than winter ones. The higher catabolic rate at low temperature for winter thalli might support the hypothesis of a modification in the enzymatic apparatus in a long-term acclimation process. Further studies involving protein analysis may elucidate this point.

The photosynthetic performance of summer thalli after a short-term acclimation to winter temperature differs to that with the overall seasonal acclimation. As stated previously, $P_{\mathrm{m}}$ per biomass unit may be viewed as an index of the number of reaction centres (RCs), whereas $P_{\mathrm{m}}$ normalised by chlorophyll a content is indicative of the chlorophyll a percentage allocated in the light harvesting system. However, these definitions only hold true when a definite turnover time for RCs is assumed (Lobban et al. 1985). By simply comparing results obtained at the same temperature with RSa and RW thalli, we might conclude that the number of RCs per biomass unit is the same in the 2 seasons, as well as the chlorophyll a partitioning between RCs and the light harvesting system. But, on the other hand, results on pigment analysis revealed a chlorophyll a content about twice as high in summer than in winter thalli, implying a probable different turnover time for RCs in summer and winter. The different turnover time suggests a change of the enzymatic apparatus, occurring on a seasonal scale and not detectable after an overnight acclimation.

The short-term acclimation experiment revealed an increase of $\alpha$ value at low temperature for summer samples of Caulerpa racemosa var. occidentalis, in accordance with the results of Terrados \& Ros (1992) who analysed summer and winter thalli of Cauterpa prolifera collected along the Spanish coast. At low temperature, in summer thalli, an increase of $\alpha$ was registered, while, in winter samples, $\alpha$ decreased at high temperature.
The pigment content analysis showed chlorophyll a concentration increases in winter, as well as the concentration of the 3 most important accessory pigments of the light harvesting system: chlorophyll $b$, siphonaxanthin and siphonein. Ratios between each of these 3 pigments and chlorophyll a do not substantially vary between the 2 seasons in question. The increased concentrations of light harvesting pigments might be due to an increase in the light harvesting efficiency during winter, characterised by a lower light regime. However, the similar ratio between chlorophyll $b$, siphonaxanthin or siphonein and chlorophyll a could be due to the same quality of available light for RS and RW thalli.

Surprisingly, concentrations of lutein (photoprotective pigment) and antheraxanthin (intermediate pigment of the xanthophyll cycle) are higher in winter than in summer and, moreover, the xanthophyll cycle proceeds to zeaxanthin synthesis only in winter. High values of lutein, antheraxanthin and zeaxanthin versus chlorophyll a ratios indicate a development of the photoprotective mechanisms. These features suggest that in winter Caulerpa racemosa is more sensitive to high light values, probably in relation to a higher harvesting pigment content. Another explanation might be that the lowest temperature in winter, implying a lower rate of enzymatic reactions involved in the dark step of photosynthesis (Vanema et al. 1999) and in the enzymatic process of repair (Kyle 1987, Aro et al. 1990, Calberg et al. 1992), might determine photo-oxidative damage also at a low light intensity.

Thus, we can conclude that seasonal acclimation involves biochemical and physiological responses to changes in temperature and light, allowing, in winter, the persistence of a reduced algal biomass, but, at the same time, sufficient to ensure the massive spreading occurring in the next favourable season.

In plants, there are 2 different ways of adaptation to light intensity (Lobban et al. 1985). The first one corresponds to a change in the number of reaction centres (as indicated by $P_{\mathrm{m}}$-fw value) in relation to light availability, while photosynthetic efficiency $(\alpha)$ does not change. The second one is an increase of $\alpha$ at lower irradiance level, while $P_{\mathrm{m}}$-fw remains constant. Few studies on seaweeds have been conducted. Our results on Caulerpa racemosa var. occidentalis are consistent with both strategies, showing a remarkable plasticity in photosynthetic traits. In fact, for an optimal exploitation of light in the $C y$ modocea nodosa canopy, the alga adopts the first strategy, while over the seasonal cycle, acclimation of this species seems to correspond to the second way. Moreover, C. racemosa var. occidentalis shows a certain plasticity of its pigment pool, modifying amounts and/or ratios in relation to variability of the environmental light.

This high physiological plasticity and the well-documented morphological one ( et al. 1987) indicate a re- 
markable adaptation capacity to different microhabitats and to their temporal variations over season. This high plasticity and the successful vegetative propagation by fragmentation (Ceccherelli et al. 2001) might explain the rapid and extensive spread of this variety in a temperate area like the Mediterranean Sea.

\section{LITERATURE CITED}

Aro EM, Hundal T, Calberg I, Andersson B (1990) In vivo studies on light-induced inhibition of photosystem II and D1-protein degradation at low temperatures. Biochim Biophys Acta 1019:269-275

Buia MC, Gambi MC, Zupo V (2000) Structure and functioning of Mediterranean seagrass ecosystems: an overview. Biol Mar Med 7(2):167-190

Calberg I, Bingsmark S, Vennigerholz F, Larsson UK, Andersson B (1992) Low temperature effects on thylakoid protein phosphorylation and membrane dynamics. Biochim Biophys Acta 1099:111-117

Ceccherelli G, Campo D (2002) Different effects of Caulerpa racemosa on 2 co-occurring seagrasses. Bot Mar 45:71-76

Ceccherelli G, Piazzi L, Cinelli F (2000) Response of the non-indigenous Caulerpa racemosa (Forsskal) J.Agardh to the native seagrass Posidonia oceanica (L.) Delile: effect of density of shoots and orientation of edges of meadows. J Exp Mar Biol Ecol 243:227-240

Ceccherelli G, Piazzi L, Cinelli F (2001) The role of vegetative fragments in the recruitment process of Caulerpa taxifolia and Caulerpa racemosa. In: Gravez V, Ruitten S, Boudouresque CF, La Direac' HL, Meinesz A, Scabbia G, Verlaque M (eds) Fourth international workshop on Caulerpa taxifolia. Lerici, GIS Posidone, Marseilles, p 111-117

Clifton KE, Clifton L (1999) The phenology of sexual reproduction by green algae (Bryopsidales) on Caribbean Coral Reefs. J Phycol 35:24-34

Demmig B, Winter K, Kruger A, Czygan FC (1988) Zeaxanthin and the heat dissipation of excess light energy in Nerium oleander exposed to a combination of high light and water stress. Plant Physiol 87:17-24

Demmig-Adams B (1990) Carotenoids and photoprotection in plants: a role for xanthophyll zeaxanthin. Biochim Biophys Acta 1020:1-24

Durand C, Manuel M, Boudouresque CF, Meinesz A, Verlaque M, Le Parco Y (2002) Molecular data suggest a hybrid origin for the inavasive Caulerpa racemosa (Caulerpales, Chlorophyta) in the Mediterranean Sea. J Evol Biol 15: 122-133

Famà P, Wysor B, Kooistra WHCF, Zuccarello GC (2002) Molecular phylogeny of the genus Caulerpa (Caulerpales, Chlorophyta) inferred from chloroplast tufA gene. J Phycol 38:1-12

Gattuso JP, Jaubert J (1985) Photosynthesis and respiration of Caulerpa racemosa (Chlorophyceae, Caulerpales) grown in aquaria: effects of light and temperature. Bot Mar 28:327-332

Hamel G (1926) Quelques algues rares ou nouvelles pour la flore mediterraneenne. Bull Mus Nat Sci Nat Paris 32(6):420

Hamel G (1931) Chlorophycees de France (Suite). Rev Algol 5(3-4):383-430

James PL, Larkum AWD (1996) Photosynthetic inorganic carbon acquisition of Posidonia oceanica. Aquat Bot 55:149-157

Jeffrey SW, Humphrey GF (1975) New spectrophotometric equations for the determination of chlorophyll $a, b, c 1$, and

Editorial responsibility: Otto Kinne (Editor),

Oldendorf/Luhe, Germany c2 in higher plants, algae and natural phytoplankton. Biochem Physiol Pflanzen 167:191-194

Kageyama A, Yokohama Y, Shimura S, Ikawa T (1977) An efficient excitation energy transfer from a carotenoid, siphonaxanthin to chlorophyll a observed in a deep-water species of chlorophycean seaweed. Plant Cell Physiol 18: $477-480$

Kyle DJ (1987) The biochemical basis for photoinhibition of photosystem II. In: Kyle DJ, Osmond CB, Arntzen CJ (eds) Photoinhibition. Elsevier, Amsterdam, p 197-226

Lobban CS, Harrison PJ, Duncan MJ (1985) Light and photosynthesis. In: Lobban CS, Harrison PJ, Duncan MJ (eds) The physiological ecology of seaweeds. Cambridge University Press, New York, p 4-34

Meyer KD, Paul V (1992) Intraplant variation in secondary metabolite concentration in 3 species of Caulerpa (Chlorophyta: Caulerpales) and its effects on herbivorous fishes. Mar Ecol Prog Ser 82:249-257

Ohba H, Enomoto S (1987) Culture studies on Caulerpa (Caulerpales, Chlorophyceae). Jap J Phycol 35:178-188

Paul VJ, Fenical W (1986) Chemical defense in tropical green algae, order Caulerpales. Mar Ecol Prog Ser 34:157-169

Piazzi L, Ceccherelli G, Cinelli F (2001) Threat to macroalgal diversity: effects of the introduced green alga Caulerpa racemosa in the Mediterranean. Mar Ecol Prog Ser 210:149-159

Riechert R, Dawes CJ (1986) Acclimation of the green alga Caulerpa racemosa var. uvifera to light. Bot Mar 29:533-537

Taylor WR (1967) Caulerpa of the Israel South Red Sea Expedition. Israel S Red Sea Expedit, 1962, Resp 24:13-17

Terrados J, Ros JD (1992) The influence of temperature on seasonal variation of Caulerpa prolifera (Forsskal) Lamouroux photosynthesis and respiration. J Exp Mar Biol Ecol 162: $199-212$

Vanema JH, Posthumus F, Van Hasselt PR (1999) Impact of suboptimal temperature on growth, photosynthesis, leaf pigments and carbohydrates of domestic and high-altitude wild Lycopersicon species. J Plant Physiol 155:711-718

Verlaque M, Boudouresque CF, Meinesz A, Gravez V (2000) The Caulerpa racemosa complex (Caulerpales, Ulvophyceae) in the Mediterranean Sea. Bot Mar 43:49-68

Vershinin AO, Kamnev AN (1996) Xanthophyll cycle in marine macroalgae. Bot Mar 39:421-425

Vidussi F, Claustre H, Bustillos-Guzman J, Caillau C, Marty JC (1996) Determination of chlorophylls and carotenoids of marine phytoplankton: separation of chlorophyll a from divinyl-chlorophyll $a$ and zeaxanthin from lutein. J Plankton Res 18:2377-2382

Webb WL, Newton M, Starr D (1974) Carbon dioxide exchange of Alnus rubra: a mathematical model. Oecologia 17:281-291

Yokohama Y, Kageyama A, Ikawa T, Shimura S (1977) A carotenoid characteristic of chlorophycean seaweeds living in deep coastal waters. Bot Mar 20:433-436

Yokohama Y (1981) Distribution of the green light-absorbing pigments siphonaxanthin and siphonein in marine green algae. Bot Mar 24:637-640

Yokohama Y (1983) A xanthophyll characteristic of deep-water green algae lacking siphonaxanthin. Bot Mar 26(2):45-48

Young AJ, Frank HA (1996) Energy transfer reactions involving carotenoids: quenching of chlorophyll fluorescence. J Photochem Photobiol B: Biol 36:3-15

Zimmerman RC, Reguzzoni JL, Alberte RS (1995) Eelgrass (Zostera marina L.) transplants in San Francisco Bay: role of light availability on metabolism, growth and survival. Aquat Bot 51:67-86

Submitted: June 10, 2003; Accepted: December 2, 2003

Proofs received from author(s): April 16, 2004 